\title{
OPTIMIZATION OF ECONOMIC INDICATORS IN A CARPENTRY COMPANY THROUGH INTEGER PROGRAMMING
}

\author{
Luis Carlos de Freitas ${ }^{2 *}$ and Ana Paula da Silva Barros ${ }^{3}$
}

\author{
${ }^{1}$ Received on 11.12.2020 accepted for publication on 29.03.2021. \\ ${ }^{2}$ Universidade Estadual do Sudoeste da Bahia, Departamento de Fitotecnia e Zootecnia, Vitória da Conquista, BA - Brasil. E-mail: \\ $<$ luisfreitas@uesb.edu.br>. \\ ${ }^{3}$ Universidade Estadual do Sudoeste da Bahia, Programa de Pós-Graduação em Ciências Florestais, Vitória da Conquista, BA - Brasil. \\ E-mail:<apsbarros_eng3@hotmail.com>. \\ *Corresponding author.
}

\begin{abstract}
This study aimed to analyze the economic feasibility of manufacturing frames in a carpentry company through two scenarios, including the production before and after modeling using operational research. The annual costs and revenues were quantified considering a horizon of 30 years. The economic analysis included the following criteria: Net Present Value (NPV), Equivalent Periodic Value (EPV) and Revenues Cost Ratio $(\mathrm{R} / \mathrm{C})$. The modeling was applied after analysis of the standard production using an objective function to maximize the company's profit based on the quantity of each assortment to be produced. The standard production showed economic feasibility for all evaluated indicators, however implementing the operational research provided an increase of $57.54 \%$ for the NPV and EPV indicators, and $11.29 \%$ for the R/C ratio. In applying the sensitivity analysis after modeling, it was noticed that the value obtained for the NPV indicator was higher, even with a $10 \%$ increase in labor costs or in the price of wood, when compared to the standard production scenario before the modeling and without applying sensitivity analysis.
\end{abstract}

Keywords: Operational research, Economic viability,Sensitivity analysis.

\section{OTIMIZAÇÃO DE INDICADORES ECONÔMICOS EM UMA CARPINTARIA PELO USO DA PROGRAMAÇÃO INTEIRA}

\begin{abstract}
RESUMO - Objetivou-se com esta pesquisa analisar a viabilidade econômica na fabricação de esquadrias em uma carpintaria, mediante dois cenários de produção, antes e após modelagem pela pesquisa operacional. Quantificou-se os custos e receitas anuais, sendo estes projetados para um horizonte de 30 anos. A análise econômica contemplou o Valor Presente Líquido (VPL), Valor Periódico Equivalente (VPE) e a Razão Receital Custo $(R / C)$. Após análise da produção padrão da carpintaria, aplicou-se a modelagem para maximização do lucro com base no quantitativo de cada sortimento a ser produzido. A produção padrão mostrou viabilidade para todos indicadores, todavia a implementação da pesquisa operacional proporcionou aumento de 57,54 $\%$ para os indicadores VPL e VPE e de 11,29\% para a R/C. Aplicando-se a análise de sensibilidade após a modelagem, percebeu-se que mesmo com aumento de $10 \%$ nos custos de mão de obra ou no preço da madeira, o valor obtido para o indicador VPL foi superior quando comparado ao cenário padrão, antes da modelagem e sem aplicação da análise de sensibilidade.
\end{abstract}

Palavras-Chave: Pesquisa operacional, Viabilidade econômica,Análise de sensibilidade. 


\section{INTRODUCTION}

Wood played a prominent role in the production of frames in past times. Metals only gained space in window and door manufacturing after the industrial revolution with the obtaining of steel on a large scale and at an affordable cost (Miotto, 2002). Thus, it is essential to rationalize the entire production process in order to ensure competitiveness for using wood in making frames.

Another important aspect is the financial planning in activities related to wood processing through economic analysis, which can survey costs and revenues in order to obtain inferences about the viability indicators. Silva et al. (2005) reports the Net Present Value, Equivalent Periodic Value and the Revenue Cost Ratio among the most relevant economic indicators.

Given the countless possibilities of producing different assortments in a carpentry company, such as: cladding; tilt and turn windows; windows/ window frames; frames/casings; doors/door frames; doors; skirting boards/baseboards, among others, the planner needs to be guided in relation to the best way to use their raw material (wood) in order to consolidate an optimal, consistent and sustainable profit, and therefore must pay attention to the study of operational research. Thus, modeling should be taken as a parameter which can promote maximizing the company's profit through an objective function and the respective restrictions based on the quantity of each assortment to be produced, thus guaranteeing better performance for the abovementioned viability indicators.

This study aimed to conduct an economic analysis on the wooden frame manufacturing process in a carpentry company, considering production scenarios before and after applying operational research.

\section{MATERIAL AND METHODS}

\subsection{Data collection}

The study was carried out in a carpentry company located in the municipality of Vitória da Conquista, BA, Brazil, in the southwest of the state. Data collection took place through interviews and questionnaires considering the characterization of the raw material, the industrial process and the commercialization of assortments. Annual costs and revenues for the year 2020 were quantified. The data were projected over a 30-year horizon due to the company's standard production flow, a period considered as the useful life estimation by carpentry.

\subsection{Determination of annual net profit}

The annual net profit was obtained via a cash flow, considering annual revenues and production costs. Costs were related to labor, wood and other inputs (glue, sandpaper, nails and energy), depreciation, machinery maintenance, fuel for product delivery and administrative costs, totaling US\$63,141.35 annually (Table 1). The raw material (wood) cost was calculated considering the product sum of the following variables: average volume of wood per assortment, numbers of each assortment made annually (Jequitiba and Jatoba wood) and the price of the cubic meter of these woods. The depreciation cost was determined using the straight-line method, taking into account the useful life of 30 years and a residual machinery value of $5.00 \%$ in relation to the acquisition price. Revenues were earned considering the quantity of each assortment offered and their respective market price.

Currency units were converted into dollars in order to stabilize costs and revenues over the planning horizon. The following conversion was used ( $\mathrm{R} \$ 5.40$ $=$ US\$1.00), the amount obtained according to the quotation made in February 2021.

\subsection{Economic analysis}

An economic feasibility analysis was performed with costs and revenues for the project under study using the following indicators: Net Present Value NPV, difference between the present value of revenues the present value of costs (Silva and Fontes, 2005); Equivalent Periodic Value - EPV, which transforms the NPV into a flow of revenues or periodic and continuous costs equivalent to the current value during the life of the project; and the Revenues-Cost Ratio $(\mathrm{R} / \mathrm{C})$, defined as a ratio between the current value of the revenues and the current value of costs (Silva et al., 2005), according to equations 1, 2 and 3, respectively.

$N P V=\sum_{j=0}^{n} R j(1+i)^{-j}-\sum_{j=0}^{n} C j(1+i)^{-j}$

Eq. 1

Revista Árvore 2021;45:e4519 
$\mathrm{EPV}=\frac{\mathrm{NPV}\left[(1+\mathrm{i})^{-\mathrm{t}}-1\right]}{\left[1-(1+\mathrm{i})^{-\mathrm{nt}}\right]}$

$R / C=\frac{\sum_{j=0}^{n} \operatorname{Rj}(1+i)^{-j}}{\sum_{i=0}^{n} \operatorname{Cj}(1+i)}$

In which: $\mathrm{Rj}=$ current value of revenues, $\mathrm{Cj}=$ current value of costs, $i=$ interest rate, $j=$ period in which revenues or costs occur, $\mathrm{n}=$ number of periods or duration of the project, $\mathrm{t}=$ number of capitalization periods between occurrence of two installments.

\subsection{Operations research}

Modeling was applied in order to maximize the carpentry company's profit based on the quantity of each assortment produced (decision variables) using integer linear programming. The following technical restrictions were considered: the annual production capacity; a guarantee of at least $80 \%$ of the quantity already produced in the standard process (for the most demanding assortments) and the annual wood volume consumed by the company.

The company has a rustic production profile, and the products are made according to the protocols established by the establishment itself. Production is standardized and of low capacity, mainly due to the reduced number of employees, which means that the company does not normally face demand restrictions for its products.

Due to the obstacles in the production process, we tried to limit the quantity of products made annually for the two species used considering the current production levels (technical restrictions 1 and 2); however, with prospects of changes in the quantities of each assortment produced by the business (doors, cladding, baseboards, tilt and turn windows, frames/casings, doors/doorframes and windows/window frames) in order to obtain a better return on investments and optimized scenarios for economic indicators. This was possible due to the different prices of the products.

Considering the greater acceptability of some assortments in carpentry, restrictions were designed so that at least $80 \%$ of the quantity already produced in the standard process was ensured, including for windows/window frames; frames/casings; doors/door frames, and doors in these cases (technical restrictions 3 and 4).
Due to the restrictions on the productive capacity of the carpentry company, it was also sought to limit the wood volume consumed annually considering the current production levels for the two species used (technical restrictions 5 and 6).

The models were elaborated based on the two sources of raw materials (Jequitiba and Jatoba wood). Considering that the decision variables must necessarily assume integer values (quantity of each assortment to be produced), the @gin function was used in the Integer programming (IP). Although rounding solutions can often seem the easiest and most practical solution to large-scale forest planning problems, this practice can lead to unsatisfactory results and often to unviable solutions, thus justifying the use of other more specific methods such as integer programming (Silva et al., 2003). After building the model, the Lingo version 3.0 program was used to obtain the data.

\section{RESULTS}

\subsection{Production costs}

The respective market prices of Jequitiba and Jatoba woods of US $\$ 277.77 / \mathrm{m}^{3}$ and US $\$ 1,055.55 / \mathrm{m}^{3}$ provided a total annual cost of raw material (wood) to the order of US\$24,822.21, corresponding to $39.31 \%$ of the annual company budget. This figure was the second most representative. The labor cost represented $51.73 \%$ of the annual expenses (Table 1). It was found that machinery depreciation was the least impacting activity in the composition of costs, representing $0.39 \%$ of the total (Table 1). The thicknesser, planer and tenoner were the equipment

Table 1 - Annual cost in the frames manufacturing process in the evaluated carpentry company.

Tabela 1 - Custo anual do processo fabril de esquadrias em madeira na carpintaria avaliada.

\begin{tabular}{|c|c|}
\hline Cost items of the carpentry company & Values (US\$) \\
\hline Labor & $32,661.00$ \\
\hline Jequitiba wood & $9,833.33$ \\
\hline Jatoba wood & $14,988.88$ \\
\hline Machinery depreciation & 199.10 \\
\hline Machinery maintenance & $3,007.20$ \\
\hline Fuel & 870.00 \\
\hline Administrative costs & 740.52 \\
\hline $\begin{array}{l}\text { Other inputs (nails, glue, sandpaper } \\
\text { and energy) }\end{array}$ & 841.32 \\
\hline
\end{tabular}

\section{Revista Árvore 2021;45:e4519}


which most contributed to this cost composition due to the higher acquisition values, representing $71.57 \%$ of the total.

\subsection{Revenues}

A total of 1,008 and 564 products were produced from Jequitiba and Jatoba wood, respectively. The amount of revenue obtained annually for the two species was US\$47,863.08 (Jequitiba) and US\$30,654.60 (Jatoba). Frame/casing production was responsible for the greatest impact on revenues, with $39.00 \%$ and $91.34 \%$, respectively for the Jequitiba and Jatoba woods.

\subsection{Application of the operations research}

After modeling and obtaining the values for the decision variables, namely the quantity of each assortment to be produced to maximize profit (Table 2), a comparative table was elaborated in relation to the production process before and after applying the operations research, considering the Jequitiba and Jatoba woods as raw materials (Table 3 ).

The algebraic formulas of the modeling are shown below.

$\operatorname{Max} . Z_{[k]}=\sum_{i=1}^{n} X_{i} Y_{i} \quad$ Para $k=1 . .2$

In which: $X_{i}$ : the decision variables referring to the quantities of each assortment produced annually (i), with these being: $X_{1}$ : Qty. of claddings; $X_{2}$ : Qty. of tilt and turn windows; $X_{3}$ : Qty. of windows/window frames; $X_{4}$ : Qty. of frames/casings; $X_{5}$ : Qty. of doors/ door frames; $\mathrm{X}_{6}$ : Qty. of doors; $\mathrm{X}_{7}$ : Qty. of skirting boards/baseboards.

$\mathrm{Y}_{\mathrm{i}}$ : assortment unit price (i);

$\mathrm{n}$ : Number of differentiated assortments for jequitiba or jatoba wood;

$\mathrm{Z}$ [1] Function Objective to maximize the revenue (jequitiba wood);

$Z$ [2] Function Objective to maximize the revenue (jatoba wood).

S.a

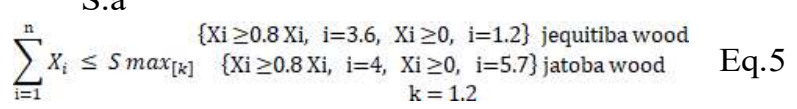

In which:

Smax[1]: Technical restriction 1 referring to the maximum quantity of products made annually with
Jequitiba wood (including all assortments), according to the production capacity of the carpentry company.

Smax[2]: Technical restriction 2 regarding the maximum quantity of products made annually with Jatoba wood (including all assortments), according to the production capacity of the carpentry company.

" $0.8 \mathrm{Xi"}$ : technical restriction 3 (guarantee of at least $80 \%$ of the quantity already produced in the standard process for the most demanding assortments) for Jequitiba wood, with these being: window/window frames $\left(\mathrm{x}_{3}\right)$; frames/casings $\left(\mathrm{x}_{4}\right)$; doors/door frames $\left(\mathrm{x}_{5}\right)$ and doors $\left(\mathrm{x}_{6}\right)$.

" $0.8 \mathrm{Xi}$ " : technical restriction 4 (guarantee of at least $80 \%$ of the quantity already produced in the standard process for the most demanded assortment) for Jatoba wood, in this case only including frames/ casings $\left(\mathrm{x}_{4}\right)$.

$\sum_{i=1}^{n} X_{i} V_{i} \leq \operatorname{Vmax}_{[k]} K=1 . .2$

Eq.6

In which:

$V \max [1]:$ Technical restriction 5 referring to the maximum volume of Jequitiba wood consumed annually according to the carpentry company's production capacity.

$V \max [2]:$ Technical restriction 6 regarding the maximum volume of Jatoba wood consumed annually according to the carpentry company's production capacity.

Xi: Assortment quantity produced annually (i);

$\mathrm{V}_{\mathrm{i}}=$ Unit volume of the assortment (i);

\subsection{Economic analysis}

The results showed attractive for all evaluated indicators when analyzing the standard production flow, however implementing the operations research provided increases of $57.54 \%$ for the NPV and EPV indicators, and $11.29 \%$ for the R/C. The EPV in the standard process showed that the project has the capacity to generate annual revenues to the order of US\$15,515.32; however, this revenue was presented in the operations research to the order of US\$24,443.96 (Table 4).

In analyzing operational research through integer programming when converting the forest into multiproduct, Campos et al. (2013) found an average

Revista Árvore 2021;45:e4519 
Table 2 - Quantity of each assortment produced by carpentry company from Jequitiba wood (A) and Jatoba wood (B) after application of the operational research.

Tabela 2 - Quantidade de cada sortimento a ser produzido na carpintaria com madeira de Jequitibá (A) e Jatobá (B), após aplicação da pesquisa operacional.

Rows $=9$ vars $=6$ No. Integer vars $=6$ (all are linear) $/ /$ Nonzeros $=30$ Constraint nonz $=18(12$ are +-1$)$ Density $=0.476 / /$ Smallest and largest elements in absolute value $=0.972000 \mathrm{E}-021008.00 / /$ No. $<: 2$ No. $=: 0$ No. $>: 6$, Obj=MAX, GUBs $<=6 / /$ Single cols $=0$

\begin{tabular}{|c|c|c|}
\hline Optimal solution found at step: & 6 & \\
\hline Objective value: & 54790.99 & \\
\hline Branch count: & 2 & \\
\hline Variable & Value & Reduced Cost \\
\hline $\mathrm{X} 1$ & $0.0000000 \mathrm{E}+00$ & 118.7000 \\
\hline $\mathrm{X} 2$ & 106.0000 & 90.74000 \\
\hline $\mathrm{X} 3$ & 153.0000 & $0.0000000 \mathrm{E}+00$ \\
\hline $\mathrm{X} 4$ & 576.0000 & $0.0000000 \mathrm{E}+00$ \\
\hline $\mathrm{X} 5$ & 125.0000 & $0.0000000 \mathrm{E}+00$ \\
\hline $\mathrm{X} 6$ & 48.00000 & $0.0000000 \mathrm{E}+00$ \\
\hline Row & Slack or surplus & Dual Price \\
\hline$\overline{\text { OBJ }}$ & 54790.99 & 1.000000 \\
\hline 2 & $0.0000000 \mathrm{E}+00$ & 120.3700 \\
\hline 3 & $0.1421526 \mathrm{E}-02$ & $0.0000000 \mathrm{E}+00$ \\
\hline 4 & $0.0000000 \mathrm{E}+00$ & -94.44000 \\
\hline 5 & $0.0000000 \mathrm{E}+00$ & -7.410000 \\
\hline 6 & $0.0000000 \mathrm{E}+00$ & -33.33000 \\
\hline 7 & 114.0000 & $0.0000000 \mathrm{E}+00$ \\
\hline 8 & $0.0000000 \mathrm{E}+00$ & $0.0000000 \mathrm{E}+00$ \\
\hline 9 & 106.0000 & $0.0000000 \mathrm{E}+00$ \\
\hline
\end{tabular}

Rows $=6$ vars $=3$ No. Integer vars $=3$ (all are linear) $/ /$ Nonzeros $=15$ Constraint nonz $=9(6$ are +-1$)$ Density $=0.625 / /$ Smallest and largest elements in absolute value $=0.900000 \mathrm{E}-02 \quad 564.000 / /$ No. $<: 2$ No. $=: 0$ No. $>: 3$, Obj=MAX, GUBs $<=3 / /$ Single cols $=0$

(B)

\begin{tabular}{|c|c|c|}
\hline Optimal solution found at step: & 7 & \\
\hline Objective value: & 32669.64 & \\
\hline Branch count: & 0 & \\
\hline Variable & Value & Reduced \\
\hline \multicolumn{3}{|l|}{$\overline{\text { Cost }}$} \\
\hline $\mathrm{X} 4$ & 432.0000 & $0.0000000 \mathrm{E}+00$ \\
\hline $\mathrm{X} 5$ & 47.00000 & -43.52626 \\
\hline$\overline{\mathrm{X} 7}$ & $0.0000000 \mathrm{E}+00$ & 16.66375 \\
\hline$\overline{\text { Row }}$ & Slack or surplus & Dual Price \\
\hline OBJ & 32669.64 & 1.000000 \\
\hline 2 & 85.00000 & $0.0000000 \mathrm{E}+00$ \\
\hline 3 & $0.2819580 \mathrm{E}-02$ & $0.0000000 \mathrm{E}+00$ \\
\hline 4 & $0.0000000 \mathrm{E}+00$ & $0.0000000 \mathrm{E}+00$ \\
\hline 5 & 47.00000 & $0.0000000 \mathrm{E}+00$ \\
\hline 6 & $0.0000000 \mathrm{E}+00$ & $0.0000000 \mathrm{E}+00$ \\
\hline
\end{tabular}

increase of $33.69 \%$ in revenue and $16.86 \%$ in the useful volume.

\subsection{Sensitivity analysis}

An additional $2 \%$ and $4 \%$ were considered in relation to the interest rate adopted $(6.00 \%)$, as well as fluctuations of $-10 \%,-5 \%,+5 \%$ and $+10 \%$ in labor and wood costs. The sensitivity analysis was designed for both scenarios (before and after modeling), as noted in Table 5.

Additions of $2 \%$ and $4 \%$ in the adopted interest rate resulted in NPV reductions of US\$38,897.65

Revista Árvore 2021;45:e4519 
Table 3 - Annual revenue before and after operational research modeling using Linear Integer Programming.

Tabela 3 - Receita anual antes e após a modelagem pela pesquisa operacional usando a programação linear inteira.

\begin{tabular}{|c|c|c|c|c|c|c|c|c|}
\hline \multirow[b]{2}{*}{ Products } & \multicolumn{5}{|c|}{ Real DataStandard production } & \multicolumn{3}{|c|}{$\begin{array}{l}\text { Data after operational research } \\
\text { modeling using Linear } \\
\text { Integer Programming (LIP) }\end{array}$} \\
\hline & $\overline{\text { Qty. }}$ & $\begin{array}{c}\text { Mean } \\
\text { Volume }\left(\mathrm{m}^{3}\right)\end{array}$ & $\begin{array}{c}\text { Total } \\
\text { Volume }\end{array}$ & $\begin{array}{l}\text { Average price } \\
\text { Unit. (US\$) }\end{array}$ & $\begin{array}{c}\text { Annual } \\
\text { Revenue (US\$) }\end{array}$ & Qty. & $\begin{array}{c}\text { Total } \\
\text { Volume }\end{array}$ & $\begin{array}{c}\text { Annual revenue } \\
\text { (US\$) }\end{array}$ \\
\hline \multicolumn{9}{|l|}{ Jequitiba wood } \\
\hline Cladding & 12 & 0.00972 & 0.11664 & 18.00 & 216.00 & 0 & 0 & 0 \\
\hline Tilt and turn windows & 12 & 0.012320 & 0.14784 & 29.63 & 355.56 & 106 & 1.30592 & $3,140.78$ \\
\hline Windows/window frames & 48 & 0.052080 & 2.49984 & 120.37 & $5,777.76$ & 153 & 7.96824 & $18,416.61$ \\
\hline Frames/casings & 720 & 0.024570 & 17.6904 & 25.93 & $18,669.6$ & 576 & 14.15232 & $14,935.68$ \\
\hline Doors/door frames & 156 & 0.07602 & 11.85912 & 112.96 & $17,621.76$ & 125 & 9.5025 & $14,120.00$ \\
\hline Doors & 60 & 0.051450 & 3.08700 & 87.04 & $5,222.40$ & 48 & 2.4696 & $4,177.92$ \\
\hline Baseboards & - & - & - & - & - & - & - & - \\
\hline Total & 1008 & - & 35.40 & - & $47,863.08$ & 1008 & 35.40 & $54,790.99$ \\
\hline \multicolumn{9}{|l|}{ Jatoba wood } \\
\hline Cladding & - & - & - & - & - & - & - & - \\
\hline Tilt and turn windows & - & - & - & - & - & - & - & - \\
\hline Windows/window frames & - & - & - & - & - & - & - & - \\
\hline Frames/casings & 540 & 0.024570 & 13.2678 & 51.85 & $27,999.00$ & 432 & 10.61424 & $22,399.20$ \\
\hline Doors/door frames & 12 & 0.07602 & 0.91224 & 218.52 & $2,622.24$ & 47 & 3.57294 & $10,270.44$ \\
\hline Doors & - & - & & - & - & - & - & - \\
\hline Baseboards & 12 & 0.0009 & 0.0108 & 2.78 & 33.36 & 0 & 0 & 0 \\
\hline Total & 564 & - & 14.20 & - & $30,654.60$ & 479 & 14.18 & $32,669.64$ \\
\hline
\end{tabular}

(18.21\%) and US\$67,304.17 (31.51\%), respectively. Studies by Virgens et al. (2015); Virgens et al. (2016); and Soares et al. (2003) confirm this tendency to reduce the attractiveness of forestry enterprises with the increase in interest rates.

In relation to wood cost fluctuations, a $10 \%$ reduction provided an addition to the NPV to the order of US\$34,151.92. Considering a $10 \%$ drop in labor costs, this addition was even greater for the respective indicator (US\$44,957.32).

In analyzing the sensitivity projection after applying the operations research, it was observed that even in the most critical scenarios (10\% interest rate; $10 \%$ increase in the cost of wood or labor), the $\mathrm{NPV}, \mathrm{EPV}$ and $\mathrm{R} / \mathrm{C}$ indicators were still superior when compared to standard values without sensitivity analysis and before implementing the operations research (Table 5).

\section{DISCUSSION}

\subsection{Revenue in the production process}

The cladding, tilt and turn windows and baseboards proved to be less expressive in the composition of total revenue, mainly due to low demand and lower market prices in relation to the other assortments (Table 3). The lower market value for Jequitiba wood provided greater attractiveness for the assortments from this species (Tables 3).

\subsection{Application of the operations research}

Mathematical modeling based on Integer Linear Programming needs to be further explored in the forestry area, and above all in works regarding wood processing, aiming to optimize and maximize revenues.

Considering in the modeling in this study a production of at least $80 \%$ of the quantity already produced in the standard process for the most demanding assortments for Jequitiba wood (windows/

Table 4 - Evaluation of economic indicators of evaluated carpentry company before and after operational research modeling.

Tabela 4 - Avaliação dos Indicadores econômicos da carpintaria avaliada antes e após a modelagem pela pesquisa operacional.

\begin{tabular}{lcc}
\hline Economic indicators & $\begin{array}{c}\text { Scenario before } \\
\text { operacional } \\
\text { research }\end{array}$ & $\begin{array}{c}\text { Scenario after } \\
\text { operational } \\
\text { research }\end{array}$ \\
\hline NPV (US\$) $/ 30$ anos & $213,565.76$ & $336,466.98$ \\
EPV (US\$) & $15,515.32$ & $24,443.96$ \\
R/C & 1.24 & 1.38 \\
\hline
\end{tabular}

Revista Árvore 2021;45:e4519 
Table 5 - Sensitivity analysis for the economic indicators before and after operational research modeling.

Tabela 5 - Análise de sensibilidade para os indicadores econômicos antes e após a modelagem pela pesquisa operacional.

\begin{tabular}{|c|c|c|c|c|c|c|}
\hline \multicolumn{3}{|c|}{ NPV (US\$)/30 years } & \multicolumn{2}{|c|}{ EPV (US\$) } & \multicolumn{2}{|c|}{$\overline{\mathrm{R} / \mathrm{C}}$} \\
\hline $\begin{array}{l}\text { Change of } \\
\text { the parameters }\end{array}$ & $\begin{array}{c}\text { Scenario before } \\
\text { the operational } \\
\text { research }\end{array}$ & $\begin{array}{c}\text { Scenario after } \\
\text { the operational } \\
\text { research }\end{array}$ & $\begin{array}{c}\text { Scenario before } \\
\text { the operational } \\
\text { research }\end{array}$ & $\begin{array}{l}\text { Scenario after } \\
\text { the operational } \\
\text { research }\end{array}$ & $\begin{array}{c}\text { Scenario before } \\
\text { the operational } \\
\text { research }\end{array}$ & $\begin{array}{c}\text { Scenario after } \\
\text { the operational } \\
\text { research }\end{array}$ \\
\hline \multicolumn{7}{|c|}{ Interest rate $(\%)$} \\
\hline $6 \% \mathrm{WSA}^{*}$ & $213,565.76$ & $336,466.98$ & $15,515.32$ & $24,443.96$ & 1.24 & 1.38 \\
\hline $8 \%$ & $174,668.11$ & $275,184.81$ & $15,515.32$ & $24,443.96$ & 1.24 & 1.38 \\
\hline $10 \%$ & $146,261.59$ & $230,431.12$ & $15,515.32$ & $24,443.96$ & 1.24 & 1.38 \\
\hline \multicolumn{7}{|c|}{ Labor cost (US\$) } \\
\hline WSA $*(32,661.00)$ & $213,565.76$ & $336,466.98$ & $15,515.32$ & $24,443.96$ & 1.24 & 1.38 \\
\hline Reduction of $10 \%$ & $258,523.08$ & $381,424.30$ & $18,781.42$ & $27,710.06$ & 1.31 & 1.46 \\
\hline Reduction of $5 \%$ & $236,044.42$ & $358,945.64$ & $17,148.37$ & $26,077.01$ & 1.27 & 1.42 \\
\hline Addition of $5 \%$ & $191,087.10$ & $313,988.32$ & $13,882.27$ & $22,810.91$ & 1.21 & 1.35 \\
\hline Addition of $10 \%$ & $168,608.45$ & $291,509.67$ & $12,249.22$ & $21,177.86$ & 1.18 & 1.31 \\
\hline \multicolumn{7}{|c|}{ Wood cost (US\$) } \\
\hline WSA*(24.822,21) & $213,565.76$ & $336,466.98$ & $15,515.32$ & $24,443.96$ & 1.24 & 1.38 \\
\hline Reduction of $10 \%$ & $247,717.68$ & $370,618.90$ & $17,996.41$ & $26,925.05$ & 1.29 & 1.44 \\
\hline Reduction of $5 \%$ & $230,641.72$ & $353,542.94$ & $16,755.86$ & $25,684.50$ & 1.27 & 1.41 \\
\hline Addition of 5\% & $196,489.80$ & $319,391.02$ & $14,274.77$ & $23,203.40$ & 1.22 & 1.36 \\
\hline Addition of $10 \%$ & $179,413.84$ & $302,315.06$ & $13,034.22$ & $21,962.86$ & 1.19 & 1.33 \\
\hline
\end{tabular}

window frames; frames/casings; doors/door frames and doors), a maximum amount of products made annually $(1,008)$, for a volume of 35.40 cubic meters according to one of the working conditions of the evaluated carpentry company (Table 3 ), the company would have to stop producing cladding in order to maximize profit.

Cladding presented a low market value and economically did not add advantages in optimizing revenues in relation to other products made by the company; therefore, its production is not prioritized in the post-modeling scenario (Table 2).

Considering in the modeling in this study, it would still need to increase the quantity of window/ window frames by $218.75 \%$ and reduce the frames/ casings, door/door frame, and door production by 20\% (Tables 2 and 3).

The demand for the assortments made in the carpentry company proved to be very active because it is a small quantity of products $(1,008$ and 564 specimens per year for jequitiba and jatoba wood, respectively) (Table 3). The change in the production scenario proposed by the operations research to optimize the economic indicators would not compromise the demand of the evaluated carpentry company, because in addition to the low supply capacity, the regional insertion of the company (logistics) contributed to high demand for the assortments produced.

Also considering a production of at least $80 \%$ of the quantity already produced in the standard process for the greater demand assortment for jatoba wood (frames/casings), maximum quantity of products made annually (564), with a limit volume of 14.20 cubic meters of annual wood according to one of the working conditions (Table 3), the company, aiming at maximizing profit, would have to stop producing baseboards due to the low market value and reduce the number of frames/casings by 108 units and increase the number of doors/door frames by 35 units (Tables 2 and 3$)$.

Such assortments prioritized in modeling would not be subject to demand restrictions, mainly due to the small supply potential of the evaluated company.

\subsection{Economic analysis}

Rationalizing and optimizing in the forestry sector can be consolidated as an alternative to reduce production costs. In analyzing the loss process in sawmill, Vital (2008) observed a maximum yield of $55 \%$ for hardwood, thus evidencing the importance of optimizing resources to reduce costs. 
Efficiency in the process of transforming raw materials into products by the wood sector is fundamental for reducing production costs (Biasi and Rocha, 2007) and optimizing profits. One of the factors which contribute to economic unfeasibility in the wood processing segments is related to the high rates of losses. Wood generates waste when it is processed and transformed, culminating in a considerable waste of raw material, which does not add value to a material considered so noble (Garcia et al., 2012). In this regard, maximizing economic indicators in carpentry industry promoted by operations research through changing the production scenario attenuates loss and waste processes, promoting greater economic sustainability for this sector.

The labor and wood costs represented a significant potential for annual production costs of the carpentry company (Table 1), being considered strategic in economic planning of the enterprise.

It was noticed that the change in the production scenario with the modeling application (maintaining the same quantity of manufactured product) provided a considerable increase in the NPV, EPV and R/C values. This context demonstrates that it is possible to enhance the company's revenues without the need to expand its production process, simply by directing the production focus through operations research techniques. Jequitiba wood presented a more promising response in terms of additional revenue when compared to Jatoba. This was due to the fact that this species contemplates a greater diversity of assortments, which allowed for better efficiency in reorganizing the production scenario, providing more efficient gains with modeling (Table 3 ).

\subsection{Sensitivity analysis}

The sensitivity analysis aimed to contextualize possible scenarios which may constitute a real situation for the evaluated enterprise, being of paramount importance for planning. When the sensitivity analysis was applied to production optimized by the operations research, it was noticed that even with an increase in the annual interest rate from $6 \%$ to $10 \%$, NPV was higher when compared to that obtained in the standard scenario (before modeling) and with an interest rate of $6 \%$ per year (Table 5). This indicates that the operations research was not only able to promote more consistent gains, but also to resist possible fluctuations in interest rates.

The economic indicators showed significant sensitivity in relation to the market price of wood. This can be explained by the fact that the carpentry company works with noble species of high commercial value. The evaluated sensitivity scenarios did not promote unfeasibility in the project (interest rate, market price of wood and labor cost), even in the standard condition before applying the operations research, which can prove the economic sustainability of the carpentry company.

\section{CONCLUSION}

The carpentry proved to be viable for all the analyzed criteria, including the sensitivity analysis. Operational research can be applied to the economic planning as a way to promote sustainability for this sector. Despite the lower market value for assortments from jequitiba wood, this raw material proved to be strategic in the composition of the assessed carpentry revenues, mainly due to the greater competitiveness in relation to the market price of jatoba wood. The regional insertion of the carpentry company in a highly structured commercial hub, coupled with its reduced supply capacity, contributed to the fact that the evaluated undertaking did not suffer major restrictions on the demand for its products.

\section{AUTHOR CONTRIBUTIONS}

Luís Carlos de Freitas: methodological design, analysis of results, discussion of results, technical review and writing.Ana Paula da Silva Barros: data collection, bibliographic research and writing.

\section{REFERENCES}

Biasi CP, Rocha MP. Rendimento em madeira serrada e quantificação de resíduos para três espécies tropicais. Floresta. 2007;37(1):95-108. doi: 10.5380/ rf.v37i1.7845

Campos BPF, Binoti DHB, Silva ML, Leite HG, Binoti MLMS. Conversão de árvores em multiprodutos da madeira utilizando programação inteira. Árvore. 2013;,37(5):881-887. doi: 10.1590/ S0100-67622013000500010.

Garcia FM, Manfio DR, Sansígolo CA, Magalhães

Revista Árvore 2021;45:e4519 
PD. Rendimento no desdobro de toras de Itaúba (Mezilaurus itauba) e Tauari (Couratari guianensis) segundo a classificação da qualidade da tora. Floresta e Ambiente. 2012;19(4):468-474. doi: 10.4322/ floram.2012.059

Miotto JL. Evolução das esquadrias de madeira no Brasil. UNOPAR Científica: Ciências exatas e tecnologia. 2002;1(1):55-62.

Silva GF, Leite HG, Silva ML, Rodrigues FL, Santos HN. Problemas com uso de programação linear com posterior arredondamento da solução ótima, em regulação florestal. Árvore. 2003;27(5):677-688. doi: 10.1590/S0100-67622003000500010.

Silva ML, Fontes AA. Discussão sobre os critérios de avaliação econômica: Valor Presente Líquido (VPL); Valor Anual Equivalente (VAE) e Valor Esperado da Terra (VET). Revista Árvore. 2005;29(6):931-936. doi: 10.1590/S0100-67622003000500010.
Silva ML, Jacovine LG, Valverde SR. Economia Florestal. Viçosa: UFV, 2005. 2. ed. 178 p.

Soares T, Carvalho R, Vale A. Avaliação econômica de um povoamento de Eucalyptus grandis destinado a multiprodutos. Revista Árvore. 2003;27(5):689694. doi: 10.1590/S0100-67622003000500011

Virgens A, Luz D, Moreira AC, Freitas LC. Análise econômica e de sensibilidade em projetos de reflorestamentos no estado da Bahia. Enciclopédia Biosfera. 2015;11(21):125 -129.

Virgens A, Freitas LC, Leite A. Análise econômica e de sensibilidade em um povoamento implantado no sudoeste da Bahia. Floresta e Ambiente. 2016; 23(2): 211-219. doi:10.1590/2179-8087.104914

Vital BR. Planejamento e operações de serrarias. Viçosa, MG: Editora UFV, 2008. 